\title{
Late Quaternary drainage dynamics in northern Brazil based on the study of a large paleochannel from southwestern Marajó Island
}

\author{
DILCE F. ROSSETTI ${ }^{1}$ and ANA M. GÓES ${ }^{2}$ \\ ${ }^{1}$ Instituto Nacional de Pesquisas Espaciais-INPE, OBT/DSR, Rua dos Astronautas, 1758, \\ Caixa Postal 515，12245-970 São José dos Campos, SP, Brasil \\ ${ }^{2}$ Universidade de São Paulo-USP, Instituto de Geociências, Programa de Geologia Sedimentar e Ambiental, \\ Rua do Lago, 562, Butantã, 05508-080 São Paulo, SP, Brasil \\ Manuscript received on July 24, 2007; accepted for publication on April 25, 2008; \\ presented by ALCIDES N. SIAL
}

\begin{abstract}
Marajó Island shows an abundance of paleochannels easily mapped in its eastern portion, where vegetation consists mostly of savannas. SRTM data make possible to recognize paleochannels also in western Marajó, even considering the dense forest cover. A well preserved paleodrainage network from the adjacency of the town of Breves (southwestern Marajó Island) was investigated in this work combining remote sensing and sedimentological studies. The palimpsest drainage system consists of a large meander connected to narrower tributaries. Sedimentological studies revealed mostly sharp-based, fining upward sands for the channelized features, and interbedded muds and sands for floodplain areas. The sedimentary structures and facies successions are in perfect agreement with deposition in channelized and floodplain environments, as suggested by remote sensing mapping. The present study shows that this paleodrainage was abandoned during Late Pleistocene, slightly earlier than the Holocene paleochannel systems from the east part of the island. Integration of previous studies with the data available herein supports a tectonic origin, related to the opening of the Pará River along fault lineaments. This would explain the disappearance of large, north to northeastward migrating channel systems in southwestern Marajó Island, which were replaced by the much narrower, south to southeastward flowing modern channels.
\end{abstract}

Key words: remote sensing, sedimentology, paleochannel, Marajó Island, Quaternary.

\section{INTRODUCTION}

The traditional view that the Amazon region remained environmentally stable during most of the Quaternary (e.g., Richards 1973, Heberle and Maslin 1999, Colinvaux et al. 2000, Colinvaux and Oliveira 2001, Kastner and Goñi 2003) has been replaced in favor of a more dynamic environmental model, as a larger volume of information from different field areas becomes available. Despite still under great debate, there has been an increasing number of studies recording that this region experienced significant changes in its physical environ-

Correspondence to: Dr. Dilce de Fátima Rossetti

E-mail: rossetti@dsr.inpe.br ment, as well as in the vegetation cover, due to climatic oscillations related to Late Pleistocene and Holocene glacial/interglacial episodes (Haffer 1969, 2001, Absy et al. 1991, van der Hammen et al. 1992, Latrubesse and Rancy 1998, Pessenda et al. 1998, 2001, Sifeddine et al. 2001, Van der Hammen 2001, Rossetti et al. 2004, 2005). Several authors have also stated that the physical environment in this area has been under continuous modification throughout the Quaternary due to tectonics promoted by reactivation of old fault systems, a process that would have affected sedimentation patterns even during the Holocene (e.g., Costa and Hasui 1997, Bemerguy et al. 2002, Bezerra 2003, Costa et al. 1993, 
1996, 1997, 2001, 2002, Souza-Filho 2000, Souza-Filho and Paradella 2003). In fact, many modern Amazonian river courses show evidence for tectonic control (Bemerguy 1997, Silva 2005, Rossetti and Valeriano 2006, Almeida-Filho and Miranda 2007, Rossetti et al. 2008). This large volume of works, among many others not cited herein, helps to illustrate that the evolution of Quaternary Amazonian ecosystems is a complex issue. Therefore, a much further effort is still needed in order to provide robust models aiming paleoenvironmental reconstructions, as the development of the physical setting depends not only on climate variation, but also on specific geologic processes that may have varied, both temporally and geographically. Therefore, different sedimentary successions are expected from one place to another.

In support of a dynamic evolution for Quaternary Amazonian paleoenvironments, a recent publication (Rossetti and Valeriano 2006) introduced a tectonic model for the establishment of a large paleovalley system in the lowest Amazon drainage basin. According to these authors, this paleovalley would have been fed by a north to north-northwest flowing paleo-Tocantins River. The lowest reaches of this river, which is one of the largest Amazonian tributaries, would have changed its direction into a modern northeast position, as a result of fault capture. In this process, which would have resulted in the detachment of Marajó Island from mainland, an impressive complex of paleochannels would have been left behind. Although the record of paleochannels is not a novel in Marajó Island, their presence in the western half of the island, where vegetation cover is dense, was suggested only recently in the above cited publication, based on analysis of digital topographic model obtained by interferometric synthetic aperture radar (InSAR) provided by the Shuttle Radar Topography Mission (SRTM). Characterization of these paleochannels with basis on field data remains to be provided. Taking into account the large size of the island (i.e., $40,000 \mathrm{~km}^{2}$ ), the lack of natural exposures, and the difficult access imposed by the scarcity of roads, dense vegetation and frequent flooding, this will be a longterm, though essential, task for precisely demonstrating the presence of these paleochannels and understand their evolution in this area.
This study aims to provide sedimentological descriptions of a large paleochannel system recognized in southwestern Marajó Island (Fig. 1A). This area was chosen due to the presence of an exceptionally welldeveloped geomorphologic feature suggestive of a paleochannel network on SRTM topographic data and the good accessibility provided by an unpaved road. This crosses over the main paleochannel which is hidden below the dense forest. In addition to provide the first sedimentological record of Quaternary deposits in western Marajó Island, the data provided herein allow to reconstruct the depositional dynamics through time and to discuss the possible controlling mechanism(s) responsible for channel abandonment in that area.

\section{GEOLOGIC FRAMEWORK}

The study area is located at the margin of the Limoeiro Sub-basin, which represents the central rift that composes the Marajó Graben System (Fig. 1A). This structure is defined by NW-SE and NE-SW normal faults, as well as NE-SW and ENE-WSW strike-slip faults reactivated from basement (Azevedo 1991, Costa and Hasui 1997) during the opening of the Equatorial South Atlantic Ocean. The rift experienced two extensional phases. The first one is related to the opening of the Equatorial South Atlantic Ocean in the late Jurassic and early Cretaceous (Szatmari et al. 1987), with a second, and more important, extensional episode taking place in the Aptian-Albian transition (Azevedo 1991).

The southwestern margin of the Limoeiro Subbasin, where the study area is located, displays higher subsidence relative to other areas of the basin (Carvajal et al. 1989), being characterized by low angle, northeastward dipping listric faults (Teixeira 1987). The sedimentary pile that filled up this depression consists of a nearly 12,000 m-thick succession represented, at the base, by sandy deposits of the Breves/Jacarezinho Formations (Aptian-Cenomanian), and silty mudstones of the Anajás Formation (Early Cretaceous). These units (Fig. 1B), attributed to depositional environments ranging from fluvial to shallow marine, are overlain by sandstones, mudstones and conglomerates of the Limoeiro Formation (Late Cretaceous), also related to fluvialshallow marine settings. Tertiary deposits overlying the Cretaceous succession consist of mixed siliciclastic- 
carbonates of the Marajó Formation (PaleoceneEocene), as well as of the Pará Group (Miocene to Holocene), altogether included in transitional to shallow marine depositional settings. The latter encompasses sandstones of the Tucunaré Formation and mudstones of the Pirarucu Formation, which are age-equivalent to the Barreiras Formation and the post-Barreiras sediments that occur in surface (Rossetti et al. 1989, 1990, Rossetti 2001).

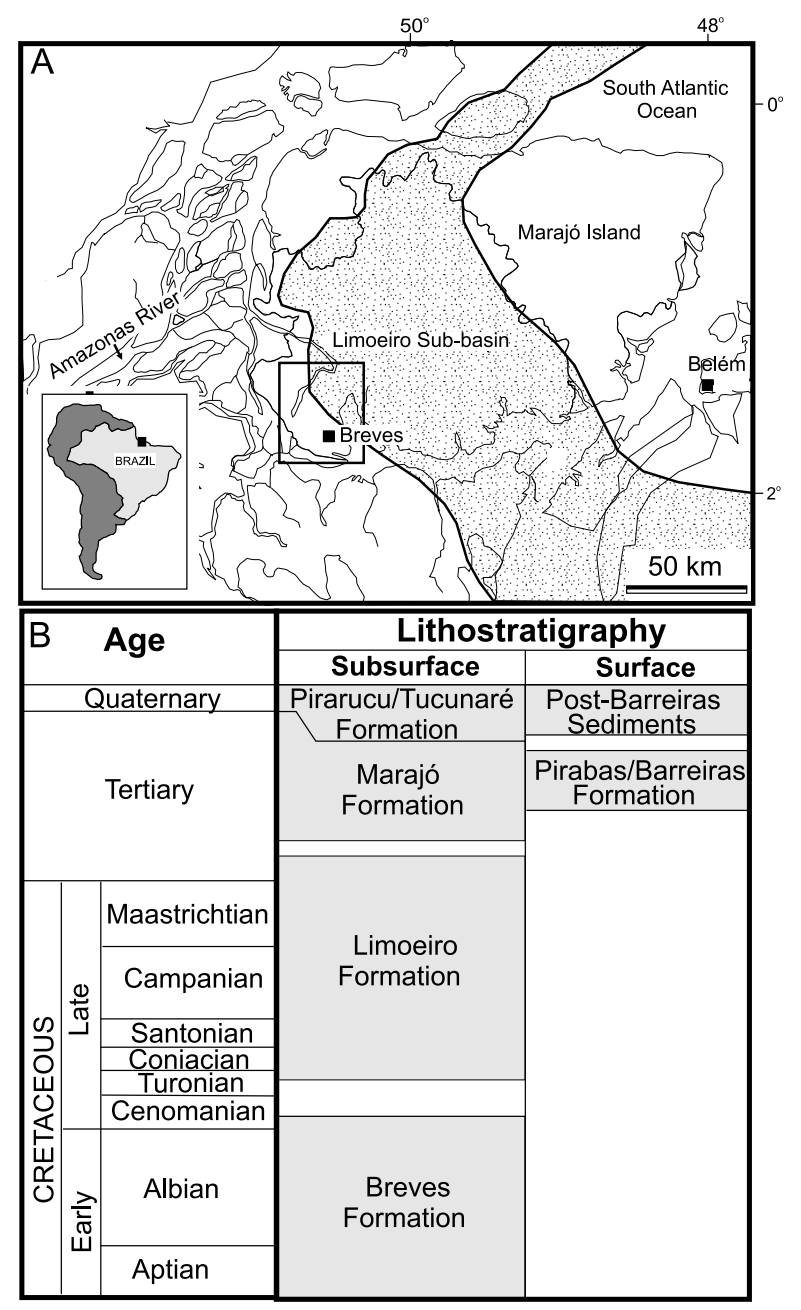

Fig. 1 - A) Location map of the study area in southwestern Marajó Island, to the northeast of the town of Breves, Limoeiro Sub-Basin of the Marajó Graben System (dotted area). B) Simplified stratigraphic chart of the Limoeiro Sub-Basin.

\section{STUDY AREA AND METHODS}

The study area in southwestern Marajó Island is located almost $25 \mathrm{~km}$ to the northeast of the town of Breves. The climate is tropical, with a mean annual temperature of $28^{\circ} \mathrm{C}$ and precipitation of 2,500 to $3,000 \mathrm{~mm} /$ year, $90 \%$ of which concentrated between January and July. In Koppen's classification, the southern part of the island is described as Af (forest tropical climate). Vegetation consists mostly of dense ombrophyla forests.

The recognition of the studied paleochannel was possible through the analysis of interferometric synthetic aperture radar (InSAR) data obtained during the Shuttle Radar Topography Mission (SRTM). These were downloaded in August 2003 from the USGS Seamless Data Distribution System (http://srtm.usgs.gov/data/ obtainingdata.html), in the first version, now known by "unfinished" dataset, in TIFF format. Elevation data were interpreted using the software Global Mapper (Global Mapper Software LLC). Given the very low topography, the study area had to be visualized accordingly using customized shade schemes and palettes to efficiently highlight the morphologic features of interest to this paper. Color schemes were rearranged to present strong hue transitions near the height of terrain unit boundaries, often requiring adjustments from a local to another. This procedure revealed a palimpsest drainage system with an incredible precision underneath the dense vegetation cover, which is either not visible or only insinuated in other radar or optical remote sensing products, such as Landsat and L-band synthetic aperture radar images of the Japanese Earth Resources Satellite (JERS-1).

The sedimentologic data consisted on the detailed descriptions of three continuous cores collected on shallow drills using a RKS percussion drilling system, model COBRA mk1. This system allowed sampling of cores with $5 \mathrm{~cm}$ in diameter up to a depth of $18 \mathrm{~m}$. Descriptions included definition of sedimentary facies based on characteristics as lithology, structure and fossil content, observing the vertical facies relationships and lateral correlations. The sedimentary facies were properly photographed and recorded in lithoestratigraphic profiles.

The chronology was based on radiocarbon analysis undertaken at the AMS-Labor Erlangen. Only two samples were dated, as most of the cores record sandy 
deposits not suitable for ${ }^{14} \mathrm{C}$ dating, and also because the results revealed ages too old already at shallow depths. Samples of peat and organic sediment were dated by accelerator mass spectrometer (AMS). The samples were pre-treated with acid to remove carbonates and weaken organic bonds, washed with alkali to remove secondary organic acids, and then combined with acid again to provide more accurate dating.

\section{MORPHOLOGIC CHARACTERIZATION}

Analysis of processed SRTM data revealed, with great precision, a palimpsest drainage system consisting of large paleochannels, characterized by a highly sinuous meander that averages $2.6 \mathrm{~km}$ wide and $30 \mathrm{~km}$ long, and encompasses almost $80 \mathrm{~km}^{2}$ (Fig. 2). This main meander continues southward following a straighter course through a distance of up to $15 \mathrm{~km}$, where it bends slightly to the southeast, proceeding with its track for more than $18 \mathrm{~km}$, when it reaches the margin of the island defined by the Pará River. The main paleochannel is connected to tributaries formed by a network of much narrower (>0.4 km wide) paleochannels that are particularly well-developed northward of the main loop to the north. Part of this paleodrainage is in the process of erosion by local modern rivers, which have in the main channel their headwaters.

Although the studied paleodrainage network does not give good indication of the main flow directions, when combined with other paleochannel systems that occur in its adjacency, an overall north to northeast paleoflow is suggested.

\section{FACIES DESCRIPTION}

Mapping of the studied paleodrainage with remote sensing data provided the basis to plan on the present sedimentologic investigation. Since areas with dense vegetation on the main channel loop avoided entrance of the drilling equipment, we used the mapped feature for plotting the drills following a distribution that would be representative of the paleochannel system (Fig. 2). Hence, two drills were made in order to record the main channel, one located at the southern end of the main sinuous meander (Drill \#1), and the other one in the straighter channel segment, circa $6.4 \mathrm{~km}$ northeastward of the town of Breves (Drill \#2). In addition, a third drill (Drill \#3) was plotted eastwards of Drill \#1, in an area where we expected to record floodplain deposits, following interpretation provided by SRTM data.

\section{Drill \#1 (Main Channel to The North)}

This drill reached $17 \mathrm{~m}$ deep and is mostly represented by a typical fining and thinning upward sedimentary succession consisting of $13 \mathrm{~m}$ of very well to well-sorted and well-rounded sands, which grade upward into a $0.5 \mathrm{~m}$ thick-package of muds (Fig. 3A). Cross-stratified sands are far the most abundant facies in this main succession, being represented by grey, medium to coarse grained, thickly (i.e., metric-scale) cross-stratified sands at the base that progressively grade upward into gray to reddish, medium and fine sands with thinner (i.e., centimeter scale) cross sets. The cross stratification is better developed at the base (Fig. 3B), where reactivation surfaces marked by thin (i.e., $0.03 \mathrm{~m}$ thick) mud drapes are frequent, defining foreset packages that are up to $0.3 \mathrm{~cm}$ thick. Double mud drapes are also locally present, and separate alternating thicker and thinner sand foresets (Fig. 3C). Heavy mineral concentrates highlight locally the foresets. The cross stratified sand facies is interbedded with either massive or deformed sands, the latter displaying convolute lamination. Intraclasts of light gray to white mud with diameter, in general, $>2 \mathrm{~cm}$ are disperse within the sandy facies. The mud at the top of this succession is massive and mottled in light red, gray and brownish yellow colors (Fig. 3D).

The main fining upward succession cuts down erosionally into a $1.5 \mathrm{~m}$-thick package of brownish, finegrained, massive sands displaying disperse plant debris, and is overlain by a $0.5 \mathrm{~m}$-thick-package of red to yellow mottled heterolithic deposits and muds, which is also sharp based and organized in a fining upward succession. The heterolithic facies is formed by well-sorted, well-rounded, very fine to fine grained sands that alternate with mud layers forming wavy and lenticular bedding, while the mud facies is massive. These deposits are overlain by a $0.5 \mathrm{~m}$ thick layer of massive sand, which is in turn sharply overlain by another $0.5 \mathrm{~m}$ thick layer of incipiently cross-stratified sands, both being well-sorted, well-rounded and very-fine to fine-grained. A sandy brownish organic soil ends this succession. 

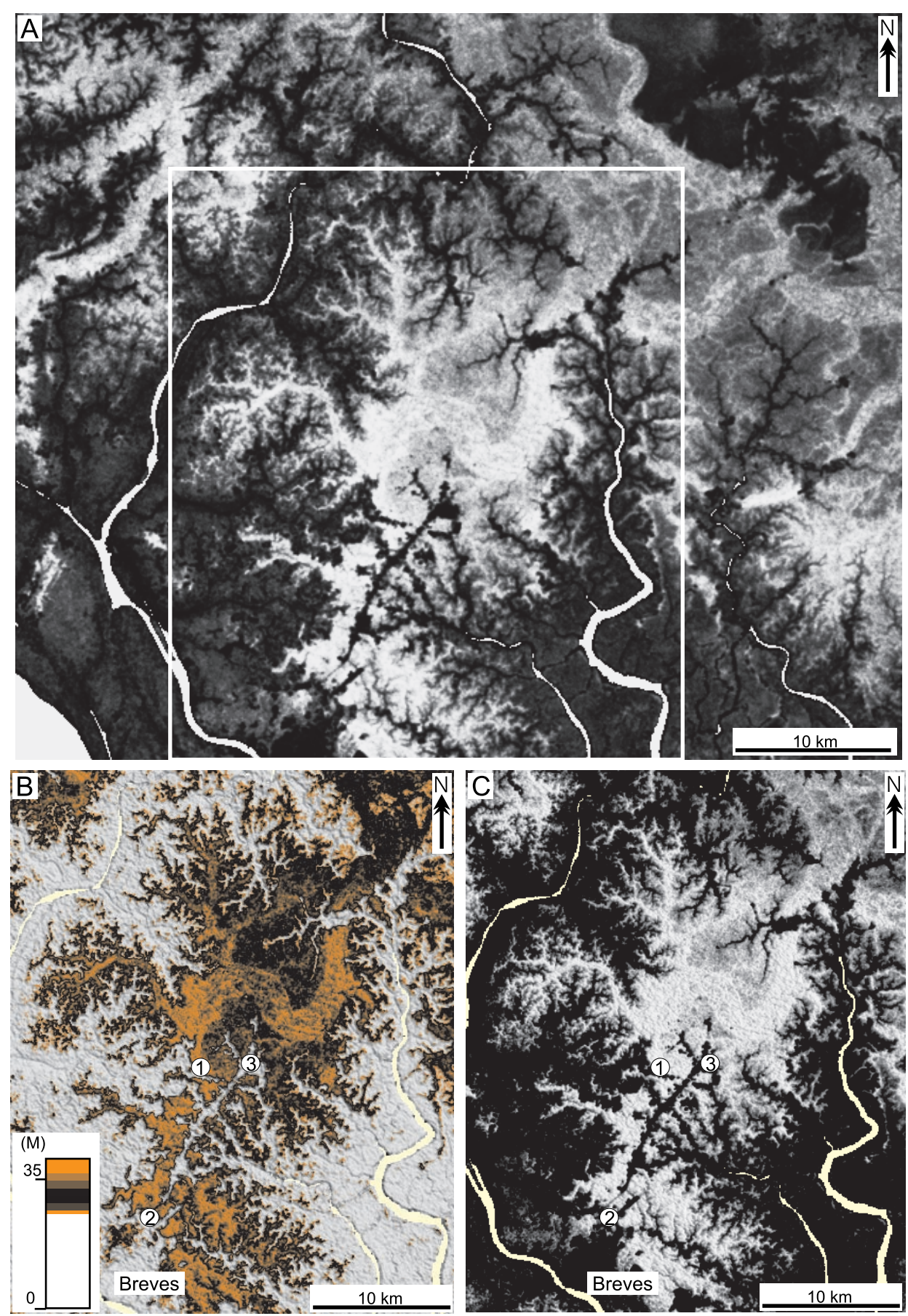

Fig. 2 - SRTM data from the study area, illustrating the sinuous belt with high elevation, attributed to paleochannels. A) A broad view of the study area in southwestern Marajó Island. Note the abundance of paleochannels, indicated by sinuous belts highlighted by bright to light gray tones, which correspond to higher digital topographic values than surrounding darker areas of lower topographies. The inside box indicates the drainage network with a large sinuous meander that is the object of this study. B and C) Details of the studied drainage network, highlighted with colors (B) and gray tones (C) (Gray scale in $\mathrm{C}$ as in A). Observe the perfectly preserved network of tributaries connected to the main meander, which resembles modern drainage systems. Note also that the main channel becomes progressively straighter to the south. Numbers indicate locations of drills \#1 to 3, illustrated in Figures 3 to 5 . 
(m)

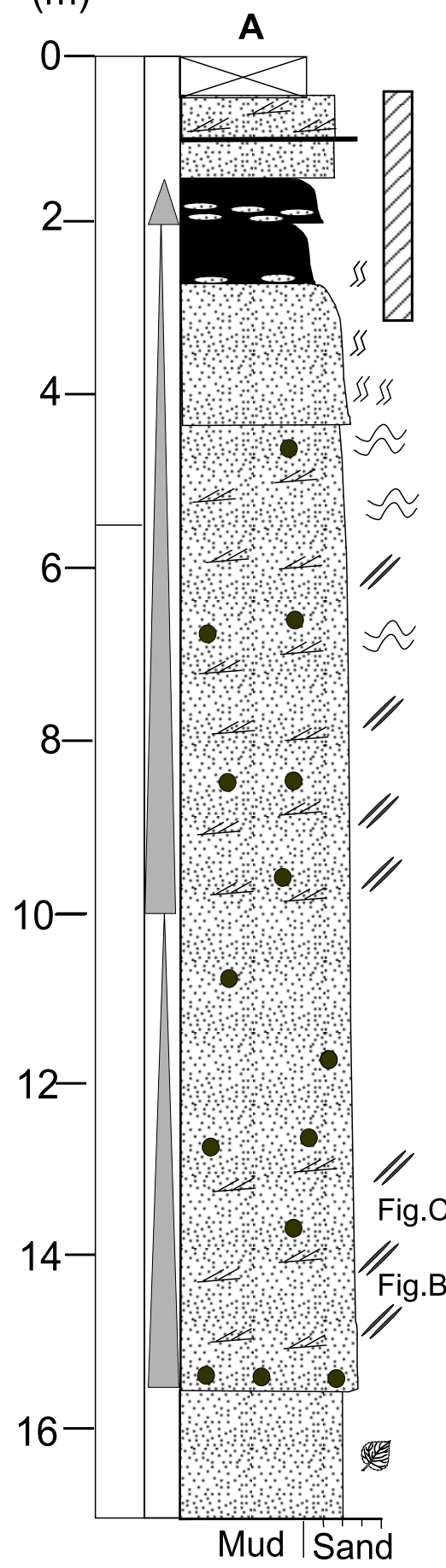

Fig.D

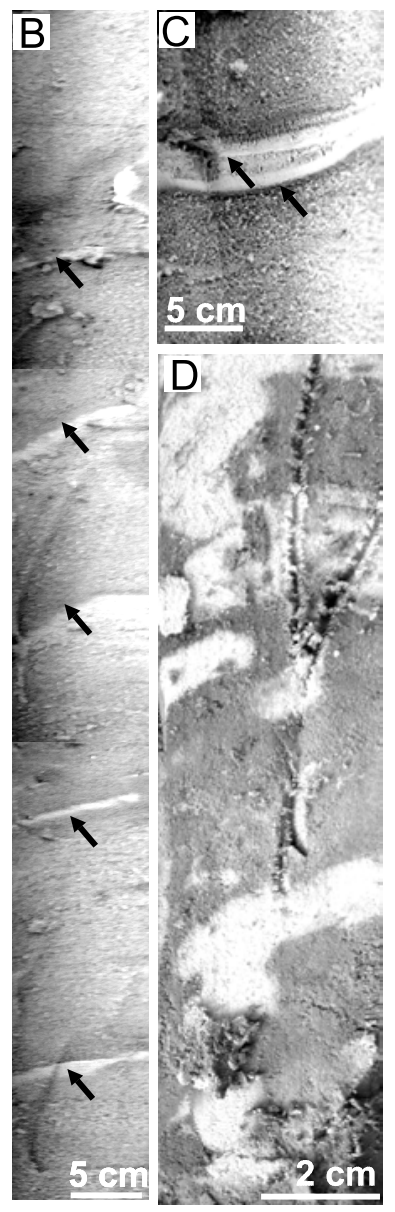

$\bigotimes$ Not recovered

Locally endured, massive mud

- Heterolithic deposit with streak and lenticular lamination

Massive sand

Laminated or cross-stratified sand

Sand with dish structure

Soil

EIII Peat

$\approx$ Convolute fold

$\downarrow$ Root and root mark

Disperse plant debris

$\mathrm{Fe}$ Iron cementation
Mudstone or sandstone intraclast

«Undetermined trace fossil

$\bigcirc$ Fragment of laterite

O Fossil invertebrate

Plant debris

$\triangle$ Fining upward cycle

$\nabla$ Coarsening upward cycle

A Active large channel deposits

B Active narrow channel deposits

C Abandoned channel or flood plain and lake deposits (including sandy inflows through small channels and deltas)

Fig. 3 - Drill \#1 (main channel to the north). A) Lithostratigraphic profile illustrating facies characteristics and vertical facies distribution. B) Cross stratified sands with foreset packages marked by reactivation surfaces and/or mud drapes (arrows). C) Detail of a cross set displaying mud couples (arrows) that define thicker/thinner sand packages, attributed to ebb/flood tidal fluctuation. D) Mottled muddy deposits from the top of the main fining upward succession, recording deposition from suspension during channel abandonment. Mottling is probably related to root development (See Figure 2 for drill location). 


\section{Drill \#2 (Main Channel to the South)}

This drill reached only $10 \mathrm{~m}$ deep and recorded a sedimentary succession consisting also mostly of white to greenish gray colored, well-rounded and well-sorted sands arranged into fining upward successions (Fig. 4A). A total of six sharp based cycles is present, with thicknesses ranging from 0.2 to $4 \mathrm{~m}$. The deposits at the base of these cycles are medium-grained and contain abundant clasts of mud with diameter $>1 \mathrm{~cm}$, and they grade upward into fine-grained sands. These are, in general, massive, though they might show local incipient stratification marked by mud drapes and heavy minerals, as observed in the previously describe drill. In one cycle, located between 5.7 and $6.3 \mathrm{~m}$, the lithology varies into sandy pit at the base and muddy pit at the top. The latter displayed a conventional age of ${ }^{14} \mathrm{C} 39,035$ $( \pm 1,018)$ yr. B.P.

The topmost $0.5 \mathrm{~m}$ of the uppermost fining upward cycle is an endured, golden yellow package of highly bioturbated, fine-grained sand cemented by iron. A trench made in this locality revealed an assemblage of trace fossils dominated by Thalassinoides, Ophiomorpha, Diplocraterion, Planolites, and possibly Teichichnus (?) and rare Skolithos (Figs. 4B to F). The walls of many traces are endured, and bioturbation increases significantly upwards. The top of this endured bioturbated sand is sharply defined by a highly sinuous, erosive discontinuity surface displaying several cylindrical depressions averaging $0.3 \mathrm{~m}$ deep (Figs. 4G-H). Above this surface, the sands are dark brown, grading upward into white sand showing sedimentologic and biogenic characteristics similar to the ones described for the strata underlying the surface.

\section{DRILl \#3 (FLOOD PlaiN)}

The core recovered from this well reached $14 \mathrm{~m}$ depth and, differently from the other two drills, it consists of sands and muds, with the latter forming packages up $3 \mathrm{~m}$ thick (Fig. 5A). The sedimentary succession starts, at the bottom, with $2 \mathrm{~m}$ of endured, greenish, reddish and yellowish mottled, either massive or convoluted muds. Root marks are present throughout this facies. The top is sharp and erosive (Fig. 5B), being overlain by a succession of fining upward cycles ranging from 0.2 to $3.5 \mathrm{~m}$ thick. As opposed to the previously described drills, the muddier parts of these cycles are, in general, thicker than the corresponding sandy portions, except between 7 and $10 \mathrm{~m}$ of depth, where sand dominates throughout the cycles, in which case the fining upward nature is defined by gradation from fine to very fine/fine grain sizes. Features resembling dish structures are observed in thicker cycles (Fig. 5C). In addition, the cycle located between 4.1 and $6.2 \mathrm{~m}$ shows the muddier portion rich in plant remains, forming pits (Fig. 5D), which displayed a conventional age beyond the radiocarbon dating method, i.e., ${ }^{14} \mathrm{C} 65,351( \pm 10,757)$ yr. B.P.

\section{DISCUSSION}

This study helped to link, for the first time, geomorphologic features in southwestern Marajó Island to large channels associated to a palimpsest drainage system, with basis on sedimentological imprint provided by core descriptions. The results obtained from this analysis furnished important information for:

1. interpreting the sedimentary processes and settings;

2. discussing the possible correlation of these paleochannels with similar features mapped in the eastern part of the island; and

3. reconstructing the evolution of the paleodrainage system in this study area, as well as the possible influencing factor(s).

\section{Sedimentary Processes and Settings}

The large feature with channellized morphology mapped in the Landsat imagery leaves no doubts of its association to a fossilized paleodrainage. This is characterized by a significant sand bedload, transported through higher energy flows than the modern channels that prevail in the study area. Sedimentary successions typical of channels were recorded throughout the cores of drills $\# 1$ and 2, and in the middle portion of drill \#3, as suggested by facies organization forming fining upward cycles, similar to many other documented channel successions (e.g., Allen 1982, Miall 1977, 1985). The sharp basis of these cycles, locally mantled by mud intraclasts or shell concentrations, records the initial stages of channel development, when energy was high enough to cause scouring of the underlying substrate, forming confined flows. The 

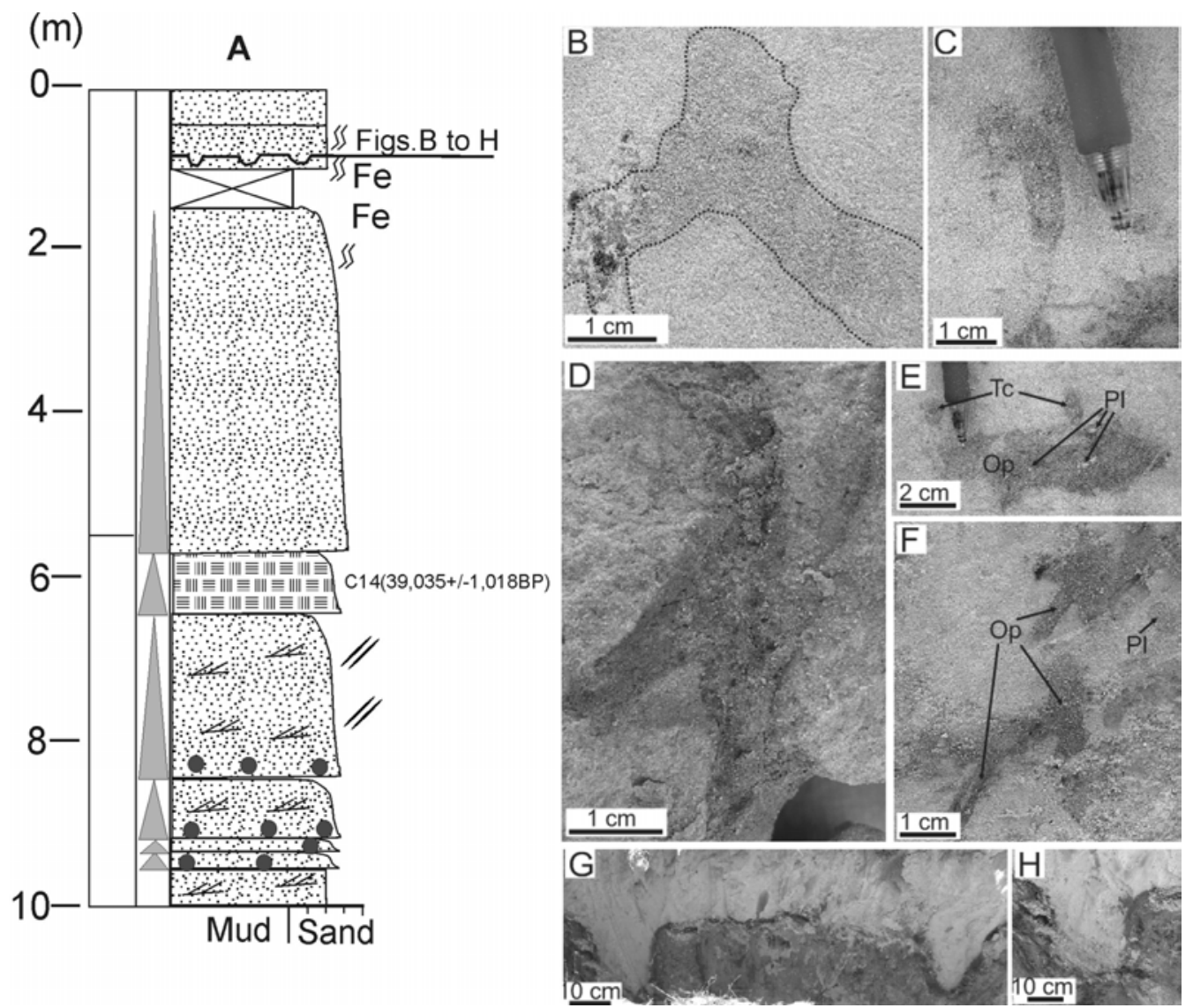

Fig. 4 - Drill \#2 (main channel to the south). A) Lithostratigraphic profile illustrating facies characteristics and vertical facies distribution. B to F) Trace fossils observed above and below the discontinuity surface at the top of the succession, illustrating: Ophiomorpha (B); Diplocraterion (C); Thalassinoides (D); Ophiomorpha (Op), Teichichnus (Tc) and Planolites (Pl) (E); and Ophiomorpha (Op) and Planolites (Pl) (F). G-H) General view $(\mathrm{G})$ and detail $(\mathrm{H})$ of large burrows developed upon the discontinuity surface of the top of the succession, probably related to feeding activity of rays. (See Figure 2 for drill location).

well-developed cross sets that occur overlying the basal surface record either migration of large to small scale bedforms at the channel bottom (e.g., Cant and Walker 1976), or sand deposition along in-channel bars (e.g., Plint 1983, Haszeldine 1983). The upward decrease in cross set size conforms to upward decreasing flow energy and shallowing that resulted in progressively smaller scale bedforms through time. The thickness of the deposits up to $13 \mathrm{~m}$ in drill $\# 1$ and the prevalence of sand facies, added to the dimension of the channel morphology recorded in surface, indicate flows with a uniform sand supply and with higher energy than the ones present today in the study area.

Although not diagnostic, the cross sets with abun- dant reactivation surfaces marked by mud drapes, which are particularly developed in the lower parts of the fining upward successions, lead to suggest possible sediment reworking by tidal currents, similarly to what has been recorded in many tidal channel successions (e.g., Boersma and Terwindt 1981, Mowbray and Visser 1984, Yang and Nio 1985, Leckie and Singh 1991, Shanley et al. 1992, Hori et al. 2001, Plink-Bjorklund 2005). In particular, the double mud drapes separating alternating thicker and thinner foreset packages, resemble structures formed by ebb/flood tidal fluctuation. However, these features are very locally developed in the study area, suggesting that, if tidal flows were present within channels, they might have only momentously left 


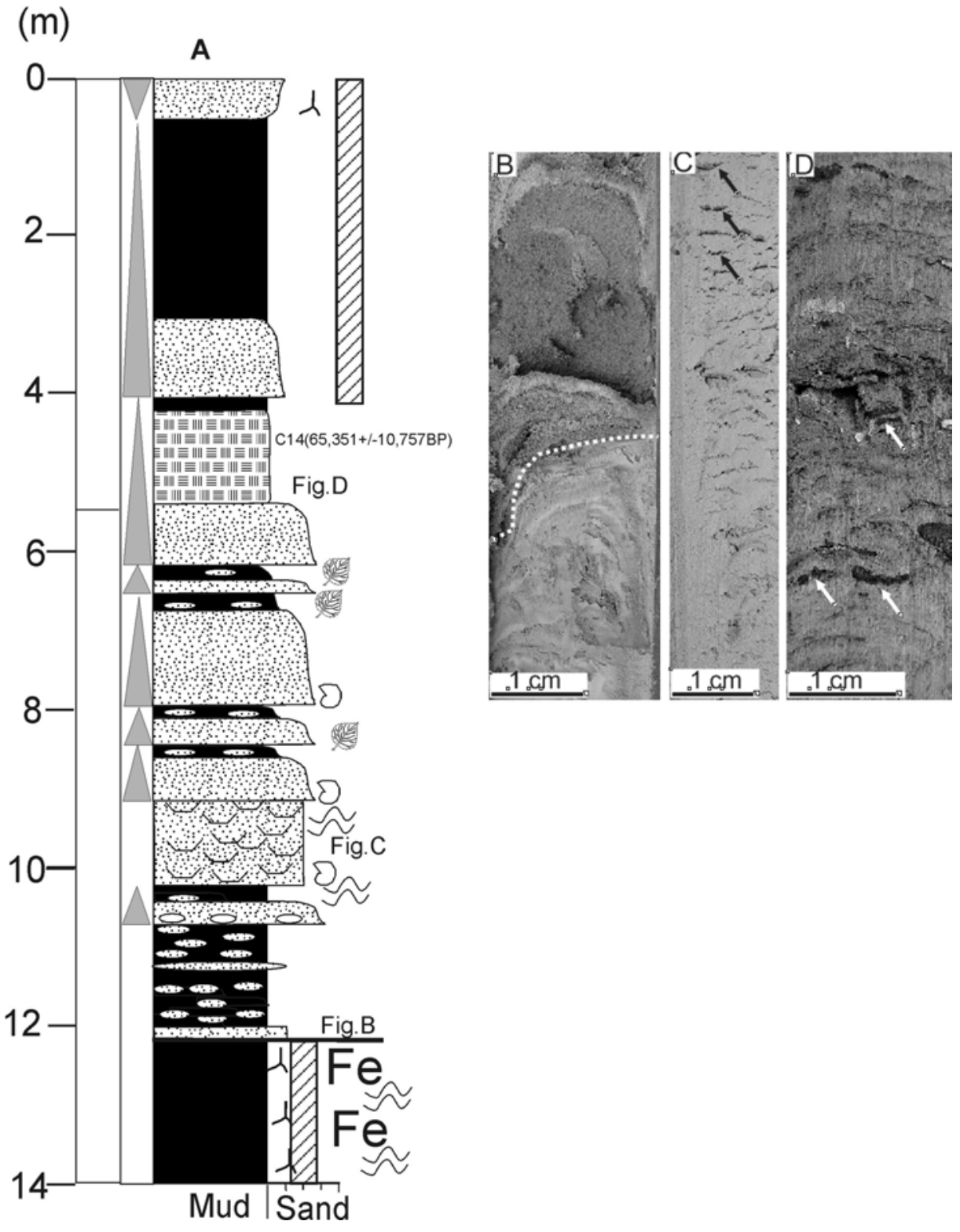

Fig. 5 - Drill \#3 (flood plain). A) Lithostratigraphic profile illustrating facies characteristics and vertical facies distribution. B) Detail of the sharp, erosive contact at $12 \mathrm{~m}$ depth, which separates endured massive muds, below, from massive sands, above. C) Sand with dish structures (arrows) from depth $=12 \mathrm{~m}$. D) Detail of pit deposits that occur in association with mud deposits from the fining upward cycle located between 4.1 and $6.2 \mathrm{~m}$ of depth (arrows indicate larger plant fragments). (See Figure 2 for drill location).

their imprint in these sediments, which is probably due to the influence of strong fluvial inflow. The overall absence of bioturbation, commonly abundant in association with many tidal channels recorded in the literature (e.g., Pemberton and Wightman 1992, Pemberton et al. 1992, MacEachern and Pemberton 1994, Rossetti 2001), conforms to a stronger influence of freshwater input relative to marine flows. Structures eventually attributed to tidal reworking, added to the dominance of well-sorted and well- to sub-rounded sands, are features that assure a coastal location for these fluvial dominated paleochannels.

The very thin muddy package at the top of the fining upward succession in drill \#1 indicates rapid channel 
abandonment, with no time for much mud deposition from suspensions. Additionally, the overall lack of mud between the sandy cycles in drill \#2 conforms to high energy flows reworking floodplain muds, which were eventually deposited during phases of channel abandonment.

The several successions of thin, but sharply based, fining upward cycles in drill \#3 are probably related to secondary channels that would have migrated over floodplain areas. These channels were also of lower energy and/or had a slower abandonment relative to channels recorded in the drills \#1 and 2, as indicated by the good preservation of muddy deposits at the top of individual cycles. The remaining of the deposits in drill \#3 record mud deposition in low energy areas surrounding the channels, thus been attributed to depositional areas related to the flood plain complex. This interpretation is quite consistent with its location adjacent to the channel morphology, as indicated by remote sensing data.

Understanding the origin of the sands that unconformably overlie the channel succession in drill \#2 is not so straightforward. The irregular discontinuity surface between these deposits indicates a depositional hiatus, accompanied by erosive processes. The highly bioturbated nature of the sands overlying the discontinuity surface, and, particularly, the types of burrows, including Thalassinoides, Ophiomorpha, Diplocraterion, Planolites, and possibly Teichichnus (?) and rare Skolithos, are similar to assemblages recorded in many high energy, shallow marine to marginal-marine environments (Ekdale et al. 1984, Wightman et al. 1987, Griffis and Suchanek 1991, Pemberton et al. 1992, 2001, Pemberton and Wightman 1992, Beynon and Pemberton 1992, Buatois et al. 1998, Gingras et al. 1999). The fact that these traces continue below the discontinuity surface, where they form an endured horizon having trace fossils characterized by hard walls, is consistent with firm grounds, typical of Glossifungites ichnofacies (Pemberton and Frey 1985, MacEachern et al. 1992). The $30 \mathrm{~cm}$ deep burrows preserved on this surface resembles similar features described in Holocene and Pleistocene sand flat deposits in the Georgia coast, which are attributed to excavations due to feeding activity of rays (Howard et al. 1977).

Thus, it appears that following a depositional hiatus and erosion, the area of drill \#2 was invaded by marine influenced waters, which would have brought marine benthics. The fauna reworked the bottom sediment, as well as the underlying substratum at a depth averaging $0.5 \mathrm{~m}$ below surface. The well preserved channel morphology, identified in the SRTM topographic data, might be taken as an indication that the marine invasion was restricted to the confined flows within channel areas. Otherwise, if an overall marine incursion took place over the entire area, it would not be expected to have a paleochannel morphology so well preserved in the modern landscape, as recorded for the study area. Therefore, a likely hypothesis is that before channel abandonment, there was a period of sediment deposition under influence of marine waters in this locality, which resulted in the thin bioturbated sandy unit at the top of drill $\# 2$.

\section{Correlation With Paleochannels in EASTERn \\ MARAJÓ ISLAND}

A work from eastern Marajó Island (Rossetti et al. in press) shows an abundance of paleochannels of Quaternary age, similarly to the ones present in the study area. The sedimentologic aspects of these deposits differ, though, particularly those near surface, which are more lithified and commonly iron-stained compared to the deposits in eastern Marajó Island. This is suggestive that deposition in western Marajó might have stopped, while eastern Marajó continued receiving sediment deposition during younger times.

In fact, two drainage networks have been recognized in eastern Marajó, which are younger than the one recorded in the present work (Rossetti et al. in press). According to these authors these consist of large and narrow channels. The latter is superimposed upon the paleodrainage system with larger channels, locally cutting through them. This was taken as indication of two stages of channel development. Radiocarbon data (Rossetti et al. in press) confirmed this interpretation as samples collected from larger paleochannel deposits indicate minimum ages of $8,850( \pm 110){ }^{14} \mathrm{C}$ yr. B.P. The narrow channels were probably formed in the late Holocene. This indicates that these channels cut into lacustrine deposits with age of 3,500 $( \pm 40){ }^{14} \mathrm{C}$ yr. B.P. Older ages up to $42,580( \pm 1,430){ }^{14} \mathrm{C}$ yr. B.P. were recorded only locally in some channel successions located several meters, or even tens of meters, from sur- 
face, usually below the discontinuity surfaces that overly endured deposits displaying evidence of paleosol development.

Although only two samples are available from the Breves area, they recorded Late Pleistocene age at a depth of only few meters below modern surface, while corresponding, and much deeper deposits, in eastern Marajó recorded mostly Holocene ages. These data led to suggest that the process of channel abandonment might have ended earlier in the eastern side of Marajó, where a younger drainage remained active through great part of the early and middle to late Holocene.

\section{Evolution of Drainage System and Influencing FACTOR(S)}

Further subsurface studies considering a more regional drill distribution and a larger sample dating are still needed in order to better reconstruct the evolution of the paleodrainage system in the Breves area. The data point to the existence of a large paleodrainage network in western Marajó Island, which slightly predated the paleodrainage recorded from eastern Marajó.

The paleochannels in southwestern Marajó Island were active up to Late Pleistocene, when they became abandoned. Although a discussion on the mechanism leading to channel abandonment is beyond the scope of this work, it is hypothesized that this process might have been related to tectonic activity. This is suggested based on a previous work, which has shown that the paleochannels in Marajó Island occur within a large paleovalley formed due to faulting (Rossetti and Valeriano 2006). According to these authors, this paleovalley would have been fed by a paleo-Tocantins River, which left behind a series of paleochannels as it migrated northeastward due to fault capture. A more recent work has also documented evidences for tectonics affecting Quaternary sediment deposition in eastern Marajó Island (Rossetti et al. 2008).

By the time the channels were active in the study area, the main flow was directed to north-northeast, which is a direction completely opposite to the south to southeast modern drainage. This abrupt change in flow direction must have occurred when the Pará River became established, which resulted in the inversion of the fluvial drainage as the area became subsided along a W-E strike slip fault (Bemerguy 1997, Rossetti and Valeriano 2006). It has been proposed that this event, which probably took place in the mid-Holocene, was responsible for the final detachment of Marajó Island from mainland (Rossetti and Valeriano 2006).

The fact that sediment accumulation within channels remained active through Holocene in eastern Marajó Island, while it ended to the west in Late Pleistocene times, is in agreement with a slight subsidence in the eastern side of the island, as previously suggested in another publication (i.e., Rossetti and Valeriano 2006). The creation of accommodation space due to tectonics in this area is further suggested by the presence of Holocene sedimentation that reaches up to, at least, $18 \mathrm{~m}$ (our unpublished data). It is not expected that only sea level fluctuation in this very low lying area could be able to preserve such a sedimentary record. In addition, these deposits overly Upper Pleistocene successions located at different depths ranging from 10-120 m, which sustains terrain displacement previously and/or contemporaneously to Holocene sedimentation.

Therefore, it is very likely that the Late Pleistocene drainage abandonment in southwestern Marajó Island is related to tectonics. As this paleodrainage was abandoned, a new drainage system became established, one formed by south to southeastward main channels that are narrower than the Upper Pleistocene paleochannels.

The establishment of the Pará River might have promoted a connection with marine waters through the Tocantins River. The marine influenced biogenic features in channel deposits located in the uppermost portions of drill \#2, might record this event.

\section{CONCLUSIONS}

This study led to the conclusion that, likewise eastern Marajó Island, the Breves area displays exceptionally well preserved geomorphologic features that can be definitively related to an ancient drainage system. Sedimentological data confirm the presence of channel deposits and the radiogenic dating points to a Late Pleistocene age. These paleochannels are slightly older than those from eastern Marajó Island, which are mostly Holocene in age. Combination of the data presented herein with previous studies supports channel abandonment due to tectonics. The establishment of the Pará 
River seems to have been crucial to promote the abandonment of a drainage network consisting of channels that were much larger than their modern counterparts and drained in an opposite south to southeast direction with respect to the ancient drainage. As the Pará River became established, a marine inflow might have taken place within segments of channels located in the southern portion of the study area.

\section{ACKNOWLEDGMENTS}

This work was funded by Fundação de Amparo à Pesquisa do Estado de São Paulo (FAPESP) (Project \#004/ 15518-6). The authors are scholarship holders of Conselho Nacional de Desenvolvimento Científico e Tecnológico (CNPq). The Goeldi Museum is acknowledged for helping with the logistic support during fieldwork. The two anonymous reviewers are thanked for their help to improve the final version of the manuscript.

\section{RESUMO}

A Ilha do Marajó mostra uma abundância de paleocanais que são facilmente mapeáveis em sua porção leste, onde a vegetação consiste principalmente em savanas. Dados SRTM possibilitam reconhecer paleocanais também na porção oeste do Marajó, mesmo considerando a cobertura vegetal de floresta densa. Uma rede de paleodrenagem bem preservada nas adjacências da cidade de Breves (sudoeste da Ilha do Marajó) foi investigada neste trabalho combinando-se sensoriamento remoto e estudos sedimentológicos. O sistema de drenagem palimpséstico consiste em um amplo meandro conectado a uma malha de tributários estreitos. Estudos sedimentológicos revelaram, principalmente, sucessões granodecrescentes ascendentes de base abrupta nas feições canalizadas, e intercalações de argilas e areias nas planícies de inundação. As estruturas sedimentares e sucessões de fácies estão em perfeita concordância com deposição em ambientes canalizados e de planícies de inundação, como sugerido pelo mapeamento com sensoriamento remoto. O presente estudo mostra que a paleodrenagem foi abandonada no final do Pleistoceno, um pouco antes dos sistemas de paleocanais holocênicos da porção leste da ilha. A integração de estudos prévios com os dados disponíveis no presente trabalho suporta causa tectônica, particularmente relacionada com a abertura do Rio Pará ao longo de falhas tectônicas. Isto explicaria o desaparecimento de canais largos que migravam para norte-nordeste no sudoeste da Ilha do
Marajó. Estes foram substituídos por outros canais mais estreitos de direção sul-sudeste que dominam na paisagem atual.

Palavras-chave: sensoriamento remoto, sedimentologia, paleocanal, Ilha do Marajó, Quaternário.

\section{REFERENCES}

ABSY ML ET AL. 1991. Mise en évidence de quatre phases d'ouverture de la forêt dense dans le sud-est de l'Amazonie au cours dès 60.000 denières années. Première comparaison avec d'autres regions tropicales. Comp Rend l'Acad Sci Paris 312: 673-678.

ALLEN JRL. 1982. Sedimentary Structures: Their Character and Physical Basis. Developments in Sedimentology 30, Amsterdan, Elsevier, 679 p.

Almeida-Filho R And Miranda FP. 2007. Mega capture of the Rio Negro and formation of the Anavilhanas Archipelago, Central Amazônia, Brazil: Evidences in an SRTM digital elevation model. Rem Sens Envir 110: $387-392$

AzEvedo AT. 1991. Tectonic evolution of Brazilian Equatorial Continental Margin Basins. Ph.D. Thesis, Univ. London.

Bemerguy R. 1997. Morfotectônica e Evolução Paleogeográfica da Região da Calha do Rio Amazonas. Tese de Doutorado, UFPA, Belém, PA, Brasil.

Bemerguy RL, Costa JBS, Hasui Y, Borges MS and SOARES JR AV. 2002. Structural geomorphology of the Brazilian Amazon region. In: KLEIN EL, VAsques ML AND Rosa Costa LT (Eds), Contribuições à Geologia da Amazônia: SBG-Núcleo Norte, p. 245-258.

Beynon BM AND Pemberton SG. 1992. Ichnological signature of a brackish water deposit: an example from the Lower Cretaceous Grand Rapids Formation, Cold Lake Oil Sands area, Alberta. In: Pemberton SG (Ed), Applications of ichnology to petroleum exploration: a core workshop: SEPM Core Workshop 17: 99-221.

BEZERRA PEL. 2003. Compartimentação morfotectônica do interflúvio Solimões-Negro. Tese de Doutorado, UFPA, Belém, PA, Brasil.

Boersma JR AND TERWINDT JHJ. 1981. Neap-spring tide sequences of internal shoal deposits in a mesotidal estuary. Sedimentology 28: 151-170.

Buatois LA, Mángano MG, Maples CG And LANier WP. 1998. Allostratigraphic and sedimentologic applications of trace fossils to the study of incised estuarine valleys: an example from the Virgilian Tonganixie Sand- 
stone Member of eastern Kansas. Curr Res Earth Sci 241: 1-27.

CANT DJ AND WALKer RG. 1976. Development of a braided-fluvial facies model for the South Saskatchewan River and the Battery Point Formation. Can J Earth Sci 13: $102-119$.

Carvajal DA, Dorman JT, Kenck AR, Key CF, Miller CJ AND Specht TD. 1989. Final report of the third exploration phase-Marajó. Texaco, Canadá, Internal Report, $61 \mathrm{p}$.

Colinvaux PA And Oliveira PE. 2001. Amazon plant diversity and climate through the Cenozoic. Palaeo Palaeo Palaeo 166: 51-63.

Colinvaux PA, Oliveira PE and Bush MB. 2000. Amazon and Neotropical plant communities on glacial time scales: the failure of the aridity and refuge hypotheses. Quat Sci Rev 19: 141-169.

Costa JBS AND HASUi Y. 1997. Evolução geológica da Amazônia. In: Costa ML AND ANGÉliCA RS (Eds), Contribuições à Geologia da Amazônia: SBG - Núcleo Norte, p. 15-19.

Costa JBS, Borges MS, Bemerguy RL, Fernandes JMG, Costa JR PS AND CostA ML. 1993. A evolução cenozóica da região de Salinópolis, nordeste do Estado do Pará. Geociências 12: 373-396.

Costa JBs, Bermeguy RL, Hasui Y, Borges MS, FERreira JR CRP, BEzERRA PEL, COSTA ML AND FERNANDES JMG. 1996. Neotectônica da região amazônica-aspectos tectônicos, geomorfológicos e deposicionais. Geonomos 4: 23-44.

Costa JBSC, Bemerguy RL, Hasui Y AND Borges MS. 2001. Tectonics and paleogeography along the Amazon River. J South Am Earth Sci. 14: 335-347.

Costa ml, Moraes EL, Behling H, Melo JCV, SiqueIRA NVM AND KERN DC. 1997. Os sedimentos de fundo da Baía de Caxiuanã. In: LisboA PLB (Ed), Caxiuanã: Mus Par Em Goeldi, p. 121-137.

Costa ML, Kern DC, Behling H AND Borges M. 2002. Geologia. In: LisBOA PLB (Ed), Caxiuanã: Populações Tradicionais, Meio Físico e Diversidade Biológica: Mus Par Em Goeldi, p. 179-206.

Ekdale AA, Bromley RG And Pemberton SG. 1984. Ichnology: the use of trace fossils in sedimentology and stratigraphy. Oklahoma, SEPM Short Course Notes 15: 317.

Gingras MK, Pemberton SG, Saunders T and ClifTON HE. 1999. The ichnology of modern and Pleisto- cene brackish-water deposits at Willapa Bay, Washington: variability in estuarine settings. Palaios 14: 352-374.

GRIFFIS RB AND SuchaneK TH. 1991. A model of burrow architecture and trophic modes in thalassinidean shrimp (Decapada: Thalassinidea). Mar Ecol Prog Ser 79: 171-183.

HAFFer J. 1969. Speciation in Amazonian forest birds. Science 165: 131-137.

HAFFER J. 2001. Hypotheses to explain the origin of species in Amazonia. In: VIEIRA ICG, SILVA JMC, OREN DC AND D'InCAo MA (Eds), Diversidade Biológica e Cultural da Amazônia: Editora do Mus Par Em Goeldi, p. $45-118$.

HASZELDINE RS. 1983. Fluvial bars reconstructed from a deep, straight channel, Upper Carboniferous coalfield of northeast England. J Sedim Petr 53: 1233-1248.

HeBerle SG AND MASLIN MA. 1999. Late Quaternary vegetation and climate change in the Amazon Basin based on a 50,000 year pollen Record from the Amazon Fan, ODP Site 932. Quat Res 51: 27-38.

Hori K, Saito Y, Zhao Q, Cheng X, Wang P, Sato Y AND LI C. 2001. Sedimentary facies of the tide-dominated paleo-Changjiang (Yangtze) estuary during the last transgression. Mar Geol 177: 331-351.

Howard JD, Mayou TV and Head RW. 1977. Biogenic sedimentary structures formed by rays. J Sedim Petr 47 : 339-346.

Kastner T And GoÑI MA. 2003. Constancy in the vegetation of the Amazon Basin during the Late Pleistocene: evidence from the organic matter composition of Amazon deep sea fan sediments. Geology 31: 291-294.

Latrubesse EM AND RANCY A. 1998. The Late Quaternary of the Upper Juruá River, southwestern Amazonia, Brazil: geology and vertebrate paleontology. Quat South Am Ant Pen 11: 27-46.

LECKIE DA AND SINGH C. 1991. Estuarine deposits of the Albian Paddy Member (Peace River Formation), and lowermost Shaftesbury Formation, Alberta, Canada. J Sedim Petr 61: 825-849.

Maceachern JA And Pemberton SG. 1994. Ichnological aspects of incised-valley systems from the Viking Formation of the Western Canada sedimentary basin, Alberta, Canada. In: DALRYMPLE RW, BOYD R AND ZAITLIN BA (Eds), Incised-valley Systems: Origin and Sedimentary Sequences: SEPM Spec Publ 51: 129-157.

MacEACHern JA, RAYChaudhuri I AND Pemberton SG. 1992. Stratigraphic applications of the Glossifungites 
ichnofacies: delineating discontinuities in the rock record. In: Pemberton SG (Ed), Applications of Ichnology to Petroleum Exploration: A Core Workshop: SEPM Core Workshop 17: 169-198.

MiALl AD. 1977. A review of the braided-river depositional environment. Earth Sci Rev 13: 1-62.

MiALL AD. 1985. Architectural-element analysis: a new method of facies analysis applied to fluvial deposits. Earth Sci Rev 22: 261-308.

MOWBRAY T AND Visser MJ. 1984. Reactivation surfaces in subtidal channel deposits, Oosterschelde, southeast Netherlands. J Sedim Petr 54: 811-824.

Pemberton SG And Frey RW. 1985. The Glossifungites ichnofacies: modern examples from the Georgia coast, USA. In: CURRAN HA (Ed), Biogenic Structures: Their Use in Interpreting Depositional Environments: SEPM Spec Publ 35: 237-259.

Pemberton SG AND Wightman DM. 1992. Ichnological characteristics of brackish water deposits. In: PEMBERTON SG (Ed), Applications of Ichnology to Petroleum Exploration: A Core Workshop: SEPM Core Workshop 17: $141-167$.

Pemberton SG, MacEachern JA And Frey RW. 1992. Trace fossil facies models: environmental and allostratigraphic significance. In: WALKER RG AND JAMES N (Eds), Facies Models: Response to Sea Level Change: Geol Assoc Can, St John's, Newfoundland, p. 47-72.

Pemberton SG, Spila M, Pulham AJ, Saunders T, MACEACHERn JA, RobBins D AND Sinclair IK. 2001. Ichnology and Sedimentology of Shallow to Marginal Marine Systems. Geol Assoc Can Short Course Notes 15: 343.

Pessenda LCR, Gomes BM, Aravena R, Ribeiro AS, Boulet R And Gouveia SEM. 1998. The carbon isotope record in soils along a forest-cerrado ecosystem transect: implications for vegetation changes in the Rondônia State, southwestern Brazilian Amazon region. The Holocene 8: 599-603.

Pessenda LCR, Boulet R, Aravena R, Rosolen V, Gouveia SEM, Ribeiro AS AND LAmotte M. 2001. Origin and dynamics of soil organic matter and vegetation changes during the Holocene in a forest-savanna transition zone, Brazilian Amazon Region. The Holocene 11: $250-254$

PlinK-BJORKLUND P. 2005. Stacked fluvial and tide-dominated estuarine deposits in high-frequency (fourth-order) sequences of the Eocene central Basin, Spitsbergen. Sedimentology 52: 391-428.
PLINT AG. 1983. Sandy fluvial point-bar sediments from the Middle Eocene of Dorset, England. In: Collinson JD AND LEWIN J (Eds), Modern and Ancient Fluvial Systems: IAS Spec Publ 6: 355-368.

Richards PW. 1973. The tropical rainforest. Sci Am 229: $58-68$.

RossetTI DF. 2001. Late Cenozoic sedimentary evolution in northeastern Pará, Brazil, within the context of sea level changes. J South Am Earth Sci 14: 77-89.

Rossetti DF AND VAlERiano MM. 2006. Evolution of the lowest Amazon basin modeled from the integration of geological and SRTM topographic data. Catena 70: 253-265.

Rossetti DF, Truckenbrodt W And Góes AM. 1989. Estudo paleoambiental e estratigráfico dos Sedimentos Barreiras e Pós-Barreiras na região Bragantina, nordeste do Pará. Bol Mus Par Em Goeldi, Sér Cienc Terra 1: $25-74$.

Rossetti DF, Góes AM And Truckenbrodt W. 1990. A influência marinha nos Sedimentos Barreiras. Bol Mus Par Em Goeldi, Sér Cienc Terra 2: 17-29.

Rossetti DF, Toledo PM, Moraes-Santos HM AND SANTOS JR AEA. 2004. Reconstructing habitats in Central Amazonia using megafauna, sedimentology, radiocarbon and isotope analysis. Quat Res 61: 289-300.

Rossetti DF, Toledo PM And Góes AM. 2005. New geological framework for Western Amazonia (Brazil) and implications for biogeography and evolution. Quat Res 63: 78-89.

Rossetti DF, Góes AM, Valeriano MM AND MiRANDA MCC. 2008. Quaternary tectonics in a passive margin: Marajó Island, northern Brazil. J Quat Sci 23: $121-135$.

Rossetti DF, Valeriano MM, Góes AM and Thalles M. (in press). Paleodrainage in Marajó Island (northern Brazil) and its relation to Holocene relative sea-level. The Holocene.

Shanley KW, McCABe PJ And Hettinger RD. 1992. Tidal influence in Cretaceous fluvial strata from Utah: a key to sequence stratigraphic interpretation. Sedimentology 39: 905-930.

SifEddine A, MARINT L, TURCQ B, VolkMER-Ribeiro C, Soubiès F, Cordeiro RC And Suguio K. 2001. Variations of the Amazonian rainforest environment: a sedimentological record covering 30,000 years. Palaeo Palaeo Palaeo 168: 221-235.

Silva CL. 2005. Análise da tectônica cenozóica da região de Manaus e adjacências. Tese de Doutorado. UFAM, Manaus, AM, Brasil. 
SOUZA-FILHO PWM. 2000. Tectonic control on the coastal zone geomorphology of the northeastern Pará State. Rev Bras Geocienc 30: 523-526.

SouzA-Filho PWM ANd PARAdella WR. 2003. Use of synthetic aperture radar for recognition of coastal geomorphological features, land-use assessment and shoreline changes in Bragança coast, Pará, northern Brazil. An Acad Bras Cienc 75: 341-356.

SZATMARI P, FRAÇOLIN JBL, ZANOTTO O AND WOLFF S. 1987. Evolução tectônica da margem equatorial brasileira. Rev Bras Geocienc 17: 180-188.

TEIXEIRA LB. 1987. Interpretação sísmica-Projeto Marajó. PETROBRÁS/DIRGEO/DENOR. Internal Report, 24 p.

VAN DER HAMMEN T. 2001. Paleoecology of Amazonia. In: VieIRA ICG, Silva JMC, OREN DC AND D'InCAO MA (EDs), Diversidade biológica e cultural da Amazônia, Editora do Museu Paraense Emílio Goeldi, Belém, PA, Brasil, p. 19-44.
VAN Der Hammen T, DUIVENVOORden JF, LiPs JM, Urrego LE AND Espejo N. 1992. The Late Quaternary of the middle Caquetá area (Colombian Amazonia). J Quat Sci 7: 45-45.

Wightman DM, Pemberton SG and Singh C. 1987. Depositional modeling of the Upper Mannville (Lower Cretaceous), East Central Alberta: implications for the recognition of brackish water deposits. In: TILLMAN RW AND WEBER KJ (Eds), Reservoir Sedimentology: SEPM Spec Publ 40: 189-220.

YANG CS AND NIO SD. 1985. The estimation of paleohydrodynamic processes from subtidal deposits using time series analysis methods. Sedimentology 32: 41-57. 